\title{
Cleaner fruit production with green manure: The case of Brazilian melons
}

\author{
Tayane de Lima Santos a , Ana Bárbara Araújo Nunes ${ }^{a}$, Vanderlise Giongo ${ }^{\text {b }}$, \\ Viviane da Silva Barros ${ }^{c}$, Maria Cléa Brito de Figueirêdo ${ }^{c, *}$ \\ a Federal University of Ceará - UFC, Av. da Universidade, 2853, CEP 60020-181, Fortaleza, Ceará, Brazil \\ ${ }^{\mathrm{b}}$ Embrapa Semiarido, Rodovia BR-428, Km 152, s/n - Zona Rural, CEP 56302-970, Petrolina, Pernambuco, Brazil \\ c Embrapa Agroindústria Tropical, Rua Dra. Sara Mesquita, 2270, CEP 60511-110, Fortaleza, Ceará, Brazil
}

\section{A R T I C L E I N F O}

\section{Article history:}

Received 26 June 2017

Received in revised form

22 December 2017

Accepted 30 December 2017

Available online 3 January 2018

\section{Keywords:}

Life cycle assessment

Environmental impact assessment

Crop rotation

Cucumis melo

Economic evaluation

\begin{abstract}
A B S T R A C T
Cleaner fruit production has become important for producers worldwide because consumers and retail companies increasingly base their purchase decisions on environmental criteria. Green manure is a soil management practice that promotes soil nutrient enrichment and may improve crop yield. Nonetheless, the environmental impacts and economic analysis of combined green manure and tropical fruit production have not been performed. This work assesses the environmental impacts and profits resulting from the Brazilian melon, commercialized in Brazil. Melon production is analyzed under two cultivation systems: i) the conventional form practiced by farmers located in the São Francisco Valley region, Brazil, and ii) the conservationist system, based on a green manure experiment carried out in this same region. This study applies life cycle assessment to evaluate the environmental impacts of both systems, considering farm inputs production and transportation (energy power, fertilizers, pesticides, plastic, paper, and fuel) as well as melon production and transportation to the main national distribution market in São Paulo. The impact categories evaluated are climate change, soil acidification, freshwater and marine eutrophication, water depletion, human toxicity (cancer and non-cancer), and ecotoxicity. Scenario analysis is applied to assess impacts under different designed conditions for transportation, packing, and nitrogen fertilization. The profit analysis is performed by reducing the total production costs (inputs and services) from the revenue obtained from selling melons. Results indicate that the conservationist system causes lower impacts and lead to higher profit than the conventional system, for all assessed categories. The scenario analysis confirms that impacts can be further reduced in all categories when alternative melon transportation and fertilization practices are adopted. This work demonstrates that the environmental performance of Brazilian melon production can be improved with the addition of green manure and alternative transportation practices.
\end{abstract}

() 2017 Published by Elsevier Ltd.

\section{Introduction}

Green manure is a soil conservationist practice that aims to improve soil fertility, through the maintenance of the biomass produced, providing a source of nitrogen for the following crop (Baggs et al., 2000). This practice may also increase soil organic matter, maintain or increase the main crop yield in the long-term (Garcia-Franco et al., 2015), and reduce the environmental

\footnotetext{
* Corresponding author.

E-mail addresses: tayanedelimasantos@gmail.com (T.L. Santos), abarbara@deha. ufc.br (A.B.A. Nunes), vanderlise.giongo@embrapa.br (V. Giongo), vivianebarros1@ hotmail.com (V.S. Barros), clea.figueiredo@embrapa.br (M.C.B. Figueirêdo).
}

impacts of the main crop (Nemecek et al., 2015).

Melon production is characterized by being in semi-arid regions with intense use of agricultural inputs, especially synthetic fertilizers and water for irrigation. Preview studies reported environmental impacts of conventional melon production systems in Italy and Brazil. Cellura et al. (2012) presented the environmental impacts of melons produced at greenhouses in an agriculture district located in Sicily, Italy. Figueirêdo et al. (2013, 2014a) analyzed the carbon and water scarcity footprints of Brazilian melons, respectively, produced under conventional system in the exporting region of Low Jaguaribe and Açu.

Some studies regarding melon production in rotation with green manure have been performed in Brazil, assessing the beneficial 
Table 1

Melon cultivation systems under study.

\begin{tabular}{|c|c|}
\hline Melon cultivation systems & Description \\
\hline \multicolumn{2}{|c|}{ Conservationist melon production, at experimental scale } \\
\hline 1 & $\begin{array}{l}\text { Green manure with seed cocktail } 1 \text { (composed of } 75 \% \text { legumes }+25 \% \text { non-legumes) }+ \text { Cutting of green manure biomass without } \\
\text { tillage }+ \text { melon production }\end{array}$ \\
\hline 2 & $\begin{array}{l}\text { Green manure with seed cocktail } 2 \text { (composed of } 25 \% \text { legumes }+75 \% \text { non-legumes) }+ \text { Cutting of green manure biomass without } \\
\text { tillage }+ \text { melon production }\end{array}$ \\
\hline 3 & $\begin{array}{l}\text { Green manure with seed cocktail with naturally occurring vegetation }+ \text { Cutting of green manure biomass without tillage }+ \text { melon } \\
\text { production }\end{array}$ \\
\hline 4 & $\begin{array}{l}\text { Green manure with seed cocktail } 1 \text { (composed of } 75 \% \text { legumes }+25 \% \text { non-legumes) }+ \text { Cutting of green manure biomass with } \\
\text { tillage }+ \text { melon production }\end{array}$ \\
\hline 5 & $\begin{array}{l}\text { Green manure with seed cocktail } 2 \text { (composed of } 25 \% \text { legumes }+75 \% \text { non-legumes) }+ \text { Cutting of green manure biomass with } \\
\text { tillage }+ \text { melon production }\end{array}$ \\
\hline 6 & Green manure with naturally occurring vegetation + Cutting of biomass with tillage + melon production \\
\hline $\begin{array}{l}\text { Conventional melon production, at } \\
\quad \text { regional scale }\end{array}$ & Removal of spontaneous vegetation + soil covering with plastic mulching + melon production \\
\hline
\end{tabular}

effect of this system in the physical and chemical soil characteristics, weed control, reduction of water requirements, as well as melon yield increase. Faria et al. (2007) identified positive effects on both fruit quality and soil characteristics when different leguminous and grass plants were cultivated as green manure, before melon production. Teófilo et al. (2012) found that melon intercropped with green manure, in a no-tillage management of plants biomass, the weed density reduced $86.7 \%$ and the irrigation requirement, $23 \%$, when this system is compared to the conventional one. Furthermore, Giongo et al. (2016), analyzing the influence of green manure intercropped with melon on melon yield and soil quality, concluded that this is a good alternative for adding biomass and nutrients to soil, as well as increasing yield in melon farms.

In this context, a broad environmental impact assessment of combined green manure and melon production in a crop rotation system has not been undertaken. Furthermore, previews studies regarding the environmental impacts of green manure in rotation with a main crop were focused on the analysis of impacts on yields and soil quality in areas located in temperate zones (Nemecek et al., 2015).

The environmental assessment of green manure systems is important because it expands the comprehension of environmental issues regarding combined production systems, supporting farmers' identification of hot spots and of better management practices. The environmental burdens of combined rotation systems are not obvious since these systems require new materials that may increase environmental impacts, when the product life cycle is considered, and/or affect the main crop yield.

This study assesses the environmental impacts and profits obtained from the commercialization of melons, produced in irrigated farmlands at the São Francisco Valley, Brazil, under conventional and conservationist systems. The conventional system, commonly practiced by farmers in Brazil, depends on frequent agrochemical application and is based solely on melon cultivation. Conversely, the conservationist system is based on a crop rotation between melons and green manure plants. In this study, different green manure plants and soil tillage practices are compared to determine which practices result in higher environmental performance. Results support melon farmers' decision-making regarding best management practices for improving both environmental performance and profit.

Brazil is among the largest melon producers in the world. Melon production mainly occurs in the Northeast, in the irrigation districts of Ceará, Rio Grande do Norte, and São Francisco Valley. In 2013, almost $95 \%$ of the national melon production resulted from these regions (IBGE, 2015).

\section{Methodology}

This study applies a cradle-to-gate life cycle assessment (LCA), according to the ISO standards 14040 and 14044 (2006a and 2006b). The melon production area was in the São Francisco Valley that encompasses Pernambuco and Bahia State municipalities. Within this Valley, the counties with high melon production are Floresta, Ibimirim, Inajá, Lagoa Grande, Orocó, Petrolândia, Petrolina and Santa Maria da Boa Vista in the state of Pernambuco; and Campo Formoso, Curaçá, Jeremoabo, Juazeiro da Bahia, Paulo Afonso, and Sobradinho in the state of Bahia.

The climate in the São Francisco Valley is semiarid (very hot, with a rainy season in the summer), but has water access throughout the year for the irrigated districts located close to the São Francisco river. The predominant soil types in the meloncultivated areas are Vertisols, Oxisols, Ultisols, and Inceptisols (Costa et al., 2017).

\subsection{Scope and functional unit}

Two melon cultivation systems were assessed in this study: conventional and conservationist (Table 1). The conventional system is adopted by farmers while the conservationist one, is at experimental stage.

In the conventional system, melons were produced over 70 days, three times per year, in the same area, and without crop rotation. In the conservationist system, melons were cultivated once a year, intercropped with green manure (Fig. 1).

The system boundary for melons from the conventional production system was comprised of input production and transportation (energy, seeds, fertilizers, agrochemical, plastic, paperboard, and fuels), melon production in open fields, and their transportation to the distribution market. For melons produced in the conservationist system, green manure cultivation was considered in addition to these other.

The functional unit adopted was $1 \mathrm{~kg}$ of packed melon, produced in Petrolina city, in the São Francisco Valley, Pernambuco State, and transported to the São Paulo city, São Paulo State, Brazil.

\subsection{Data collection}

Primary data related to the conventional melon production system was obtained through a questionnaire from local producers operating in the Salitre Irrigated Perimeter of the São Francisco Valley. Data referred to years 2011 and 2012. This area represents an important fruit production region for the Brazilian market. In March 2015, its total cultivated area was 1446 ha, with 177 ha 

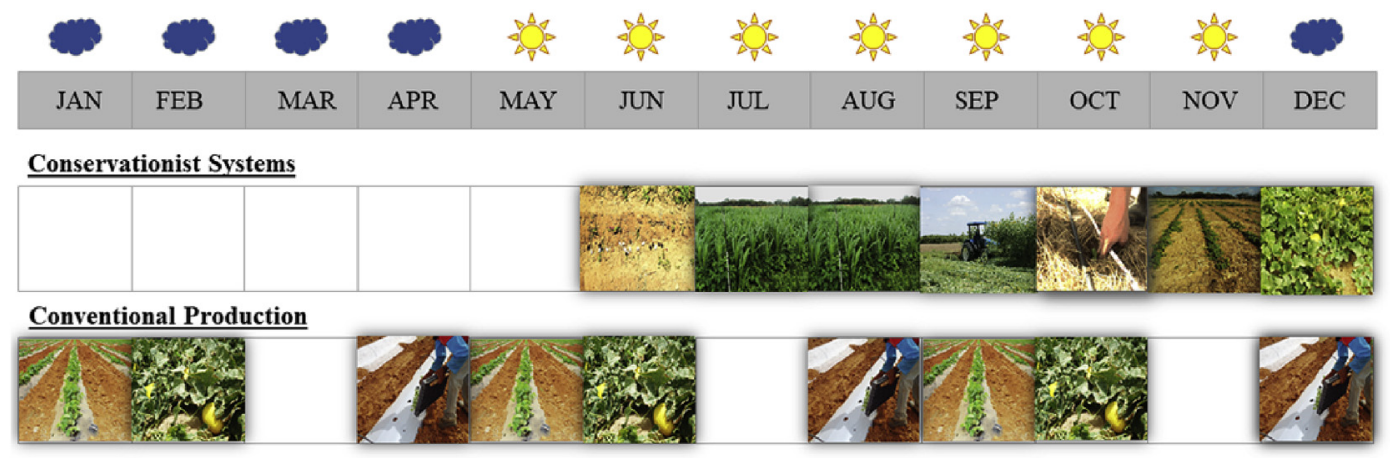

Fig. 1. Timeline of melon production in the conventional and conservationist systems.

producing melons (Consortium Salitre, 2015).

For the conservationist system, primary data was obtained from researchers of Embrapa Semiarid, who were responsible for the maintenance of a long-term experiment at the Bebedouro Experimental Farm (latitude 09009'S, longitude 40022'W and altitude $365.5 \mathrm{~m}$ ), in the São Francisco Valley. The experimental data was comprised of six years, from 2011 to 2016, and related to input use, carbon and nitrogen stocks in soil and biomass, and crop yield.

Since many species were present in the seed cocktail for green manure, a simplified method was adopted to account for the inventories of leguminous and non-leguminous seed production. Beans were selected to represent the leguminous plants, while corn represented the non-leguminous. Data referring to bean seed production was based on Souza et al. (2007). Valentini et al. (2009) and Embrapa (2008) were the sources used to develop the inventory for corn seed production. It is considered that 1 ha of beans produces $600 \mathrm{~kg}$ and 1 ha of corn, $6600 \mathrm{~kg}$ of seeds.

Secondary data regarding the production of inputs (energy, fertilizers, pesticides, diesel, pallets, plastics, and cardboard boxes) and their transportation to farm were from the ecoinvent@ 3.01 (Frischknecht et al., 2007) database. Data regarding melon seed and seedling production were from Figueirêdo et al. (2013).

To calculate the mass of material used for packing melons (pallets and cardboard boxes) in 1 ha, the weight of one unit of each material was divided by the mass of melons packed using them, and then multiplied by the total yield. For the plastic mulch used in melon production, one square meter of mulch was weighted and multiplied by the total area of mulch used in 1 ha.

\subsubsection{Melon production in the conventional system}

Commercial melon production occurred in open fields between July and December (the dry season), with the largest harvest taking place in September (Fig. 1), according to APEX Brazil (2015). Three melon production cycles occur per year in the same area.

Production included five steps: soil preparation, sowing of melon seeds, management, harvest, and field clean up. Polyethylene mulching was used to reduce water evaporation from the soil, and to prevent putrefaction of the forthcoming fruits when in prolonged contact with the moist soil. Sowing and crop management began with daily drip fertirrigation as well as disease and pest control. After 65 days, fruits were manually harvested, and the plant residues were incorporated into the soil. It was estimated that there were 11,200 melon plants per hectare, spaced at $40 \mathrm{~cm}$ intervals along the rows and $2 \mathrm{~m}$ between rows. Melons were packed in the fields in paperboard boxes with a storage capacity of $13 \mathrm{~kg}$.

\subsubsection{Melon production in the conservationist system}

In the conservationist system, melons were intercropped with green manure in an experimental area. The only commercialized product from this system was melons, as occurred in the conventional system.

The experimental design was a randomized block design with four replications. Two soil tillage systems, as plots, were studied: i) tillage (treatments 4,5 , and 6 in Table 1 ) and ii) no-tillage (treatments 1,2 , and 3 in Table 1 ). Three types of green manure were evaluated in subplots: i) vegetal cocktail with $75 \%$ legumes and $25 \%$ non-legumes; ii) vegetal cocktail with $25 \%$ legumes and $75 \%$ nonlegumes, and iii) spontaneous vegetation).

The spontaneous vegetation, which grows between melon production cycles without sowing, was composed of the following predominant species: Commelina benghalensis L., Macroptilium atropurpureum Desmodium tortuosum, and Ancanthorpermun hispidun DC.

The seed cocktail used in green manure was composed of fourteen species, including legumes and non-legumes, all adapted to the semiarid São Francisco Valley: Calopogonio (Calopogonium mucunoide), black velvet bean (Mucuna aterrina), gray velvet bean (Mucuna conchinchinensis), sunn hemp (Crotalaria juncea), rattlebox (Crotalaria spectabilis), jack bean (Canavalia ensiformes), pigeonpea (Cajanus cajan L.), lab-lab bean (Dolichos lablab L.); castor oil plant (Ricinus communis L.), sunflower (Helianthus annuus L.), sesame (Sesamum indicum L.), corn (Zea mays), pearl millet (Penissetum americanum L.) and sorghum (Sorghum vulgare Pers.).

Regarding green manure production, the seed cocktail was sowed, and drip irrigation was applied, for 70 days. Fertilizers and agrochemical defensives were not used for green manure. After this period, when most of the plants were in the flowering stage, they were tipped with a mower, for the treatments in which the green manure biomass was not incorporated into the soil. Tractors with subsoilers, bars, and plows were used for treatments with biomass incorporation. Melon seedlings were transplanted 10 days after the cocktail biomass was tipped and the melon harvest occurred 65 days after transplantation.

The amount of nitrogen and carbon present in green manure plants, spontaneous vegetation and melon plants was quantified in the Laboratory of Embrapa Semiarid. Plant samples were collected and dried at $65-70^{\circ} \mathrm{C}$ for $72 \mathrm{~h}$ to determine dry biomass, carbon and nutrient contents. Regarding the root biomass of the vegetal cocktails and spontaneous vegetation, soil samples were collected in trenches $(1.0 \mathrm{~m} \times 0.2 \mathrm{~m} \mathrm{x} 1.0 \mathrm{~m})$. Root samples were removed in soil blocks with a volume of $20 \mathrm{~cm}^{3}$ at depths of $0-0.2,0.2-0.4$, $0.4-0.6,0.6-0.8$ and $0.8-1.0 \mathrm{~m}$. The soil samples were sieved and washed in $2 \mathrm{~mm}$ sieves to separate the root samples from the soil.

The nitrogen $(\mathrm{N})$ and carbon $(\mathrm{C})$ soil stocks were measured collecting soil samples from depths of $0-5,5-10,10-20$ and $20-40 \mathrm{~cm}$, every year after the biomass from plant cocktails and spontaneous vegetation was cut. The contents of total carbon and 
nitrogen in the samples were evaluated using the Elemental Analyzer TruSpec CN Leco Model. The stocks of $\mathrm{C}$ and $\mathrm{N}$ of each soil layer were calculated from the TC and TN content and soil bulk density (Ds) based on equivalent soil layers (Bayer et al., 2006) and equivalent mass of soil (Ellert and Bettany, 1995), using Caatinga as a reference area. The Ds values at each depth were determined in undisrupted soil samples collected at the same time as the sampling for determination of TC and TN contents.

Carbon and nitrogen contents in the samples of plant cocktails and decomposed vegetation were measured by dry combustion in elemental analyzer - LECO, model CHN 600.

Melon production in the experimental area was like the one described for commercial farms (section 2.2.1), the major difference being the absence of the plastic mulch. As previously mentioned, depending on the treatment adopted (Table 1), the biomass from green manure may or may not have been incorporated into soil. Melon seedlings were either planted over the straw (no-tillage) or directly into the soil (with tillage).

\subsubsection{Melon packing and transportation}

Melons were packed, right after harvested, in cardboard boxes of $0.71 \mathrm{~kg}$, with capacity to hold $13 \mathrm{~kg}$. Packed melons were transported by closed truck, with capacity of $20 \mathrm{t}$, for $2168 \mathrm{~km}$, departing from Petrolina, Pernambuco State, to the Company of Warehouses, in São Paulo city (CEAGESP).

\subsection{Calculating the gross irrigation water requirement for melon}

The gross water irrigation requirement (GIWR) for melons cultivated in the São Francisco Valley was calculated according to FAO (1997). GIWR represents the total irrigation volume per month and is the sum of daily irrigation water multiplied by the irrigation efficiency of system ( $90 \%$ for drip irrigation in the Valley). The daily irrigation water equals the crop evapotranspiration (ETc) minus the effective rainfall. ETc is the daily reference evapotranspiration (ETo) multiplied by the crop coefficient $(\mathrm{kc})$ that changes for each phenological phase. ETo and effective rainfall were obtained from the climate station in Petrolina operated by Embrapa, considering the years 2008-2017. The values of kc adopted for each phase of the melon production cycle ( 67 days) were: i) 0.35 for the initial phase (23 days); ii) 0.7 for the vegetative phase (17 days); iii) 1 for the fruitification phase (18 days); and iv) 0.8 for the maturation phase (7 days) (Braga, 2016).

\subsection{Calculating emissions from agriculture}

Emissions for air, water, and soil derived from green manure and melon production were estimated through soil and climate information as well as considering the natural vegetation common to the São Francisco Valley (the Caatinga physiognomy in the Savanna biome). Emissions from land use change (carbon dioxide $\left(\mathrm{CO}_{2}\right)$, carbon monoxide $(\mathrm{CO})$, methane $\left(\mathrm{CH}_{4}\right)$, nitrogen oxide (NOx), and nitrous oxide $\left(\mathrm{N}_{2} \mathrm{O}\right)$ ) were calculated according to IPCC (2007) and MCT (2010). It was considered that $20 \%$ of the biomass in the natural vegetation (the Caatinga physiognomy in the Savanna biome) was burned, while the other remaining $80 \%$ decayed. Ammonia $\left(\mathrm{NH}_{3}\right)$, nitric oxide $\left(\mathrm{NO}_{\mathrm{x}}\right)$, nitrate $\left(\mathrm{NO}_{3}^{2-}\right)$, phosphorus $(\mathrm{P})$ and phosphate $\left(\mathrm{P}_{2} \mathrm{O}_{5}^{2-}\right)$ water emissions and pesticide and heavy metal soil emissions were calculated according to Nemecek and Schnetzer (2012).

Data regarding carbon and nitrogen storages in the biomass (green manure and melon) and soil at the experimental area was annually measured in accordance to the methods described by Giongo et al. (2016) and Pereira Filho et al. (2016).

Appendix A presents the questionnaire applied to gather the input data, and Appendix B shows all equations and emission factors applied for the calculation of emissions.

\subsection{Impact assessment}

The ReCiPE method (Goedkoop et al., 2013a) with hierarchical midpoint approach was applied for assessing impacts on climate change (CC), soil acidification (SA), freshwater eutrophication (FE), marine eutrophication (ME) and hydric depletion (HD). Human toxicity (cancer and non-cancer) and ecotoxicity were assessed with the USEtox method (Rosenbaum et al., 2008).

\subsection{Uncertainty and scenario analysis}

Uncertainty analysis was performed with the Monte Carlo method using the Simapro 8.0 software. The difference between the treatment causing the largest environmental impacts (A) and the treatment causing the smallest impacts (B) was considered significant when the result of A-B was larger than 95\%. It was assumed that each inventory parameter in melon production inventories had a lognormal distribution of probability function. The geometric standard deviation of these parameters was calculated applying the Pedigree Matrix (Goedkoop et al., 2013b).

Scenario analysis was performed to evaluate the environmental impacts resulting from possible variations in the reference situation for the processes of fertilization and transportation, as well as land use change. In the reference situation, it was considered that: i) nitrogen fertilization during melon production follows the recommendations provided by Mendes et al. (2016); ii) native vegetation (Caatinga) was transformed in melon farms; and iii) trucks transported melons from Petrolina city to CEAGESP, in São Paulo.

\subsection{Economic evaluation}

The profits resulting from the adoption of the conventional system and the treatment that achieve the best performance were evaluated in this study. Profit was calculated as the gross revenue minus total production costs (Paula Pessoa et al., 2017). The costs of every input and human labor were quantified, based on the mass inventory of melon production. The gross revenue obtained from melon commercialization was calculated considering the yield of each system and the selling price of US\$ $0.61 / \mathrm{kg}$ of melon.

\section{Results}

\subsection{Inventory analysis}

Melon production in the conventional system at the São Francisco Valley required higher quantities of most of the ancillary materials per hectare compared to any of the evaluated treatments in the conservationist system (Table 2). The conventional system relied on different external inputs, such as synthetic fertilizers and plastics (mulching), while the conservationist system used less or none of these inputs. However, the latter did require green manure seeds and more diesel (for sowing green manure seeds and cutting the biomass).

Regarding irrigation water, although the volume applied in the conservationist system was required to produce both green manure biomass and melons, this volume was lower than the one used in conventional system. Moreover, the comparison of the GIWR for melons produced in the São Francisco Valley $\left(2700 \mathrm{~m}^{3} / \mathrm{ha}\right.$ in Table 3), with the volume applied by farmers $\left(9000 \mathrm{~m}^{3} /\right.$ ha in Table 2) shows that farmers are overusing water in this region that is subject to water scarcity, especially during the irrigation period.

All conservationist treatments used the same amount of water, 
Table 2

Melon production inventory of conventional and conservationist systems for 1 ha of melon over one production cycle.

\begin{tabular}{|c|c|c|c|c|c|c|c|c|}
\hline \multirow[t]{2}{*}{ Inventory } & \multirow[t]{2}{*}{ Unit } & \multicolumn{6}{|c|}{ Melon production in conservationist system } & \multirow{2}{*}{$\begin{array}{l}\text { Melon production in } \\
\text { conventional system }\end{array}$} \\
\hline & & Treatment $1^{\mathrm{a}}$ & Treatment $2^{\mathrm{a}}$ & Treatment $3^{\mathrm{a}}$ & Treatment $4^{\mathrm{a}}$ & Treatment $5^{\mathrm{a}}$ & Treatment $6^{\mathrm{a}}$ & \\
\hline Melons & $\mathrm{kg}$ & $40,533.30$ & $39,773.60$ & $35,853.00$ & $38,859.70$ & $40,982.40$ & $38,143.50$ & $33,711.21$ \\
\hline \multicolumn{9}{|l|}{ Inputs } \\
\hline $\begin{array}{l}\text { Land } \\
\text { Cocktails seeds }\end{array}$ & ha & 1 & 1 & 1 & 1 & 1 & 1 & 1 \\
\hline Corn & $\mathrm{kg}$ & 52.62 & 157.87 & 0 & 52.62 & 157.87 & 0 & 0 \\
\hline Bean & $\mathrm{kg}$ & 485.25 & 161.75 & 0 & 485.25 & 161.75 & 0 & 0 \\
\hline Melon seeds & $\mathrm{kg}$ & 0 & 0 & 0 & 0 & 0 & 0 & 0.69 \\
\hline Seedlings & $\mathrm{kg}$ & 45.5 & 45.5 & 45.5 & 45.5 & 45.5 & 45.5 & 0 \\
\hline Water & $\mathrm{m}^{3}$ & 6090.35 & 6090.35 & 6090.35 & 6090.35 & 6090.35 & 6090.35 & 9000 \\
\hline Electricity & kWh & 1500 & 1500 & 1500 & 1500 & 1500 & 1500 & 1622.2 \\
\hline Diesel & 1 & 20 & 20 & 20 & 38.8 & 38.8 & 38.8 & 20 \\
\hline Gasoline & 1 & 6.7 & 6.7 & 6.7 & 6.7 & 6.7 & 6.7 & 0 \\
\hline Plastics & $\mathrm{t}$ & 26.85 & 26.85 & 26.85 & 26.85 & 26.85 & 26.85 & 65.18 \\
\hline Cardboard boxes & $\mathrm{kg}$ & 2212.71 & 2171.23 & 1957.21 & 2121.34 & 2237.22 & 2082.25 & 1840.29 \\
\hline Wood (Pallets) & $\mathrm{kg}$ & 490.04 & 480.86 & 433.46 & 469.81 & 418 & 495.47 & 407.56 \\
\hline \multicolumn{9}{|l|}{ Fertilizers } \\
\hline Organic Comp. & $\mathrm{kg}$ & 0 & 0 & 0 & 0 & 0 & 0 & 6666.67 \\
\hline $\mathrm{N}$ & $\mathrm{kg}$ & 107.57 & 107.57 & 107.57 & 107.57 & 107.57 & 107.57 & 143.56 \\
\hline $\mathrm{P}$ & $\mathrm{kg}$ & 90.75 & 90.75 & 90.75 & 90.75 & 90.75 & 90.75 & 130.68 \\
\hline K & $\mathrm{kg}$ & 62.5 & 62.5 & 62.5 & 62.5 & 62.5 & 62.5 & 129.78 \\
\hline Others & $\mathrm{kg}$ & 59.62 & 59.62 & 59.62 & 59.62 & 59.62 & 59.62 & 221.76 \\
\hline \multicolumn{9}{|l|}{ Pesticides } \\
\hline Thiamethoxam (insecticide) & $\mathrm{kg}$ & 0.175 & 0.175 & 0.175 & 0.175 & 0.175 & 0.175 & 0.25 \\
\hline Methomil (insecticide) & $\mathrm{kg}$ & 0.645 & 0.645 & 0.645 & 0.645 & 0.645 & 0.645 & 0.645 \\
\hline Abamectin (insecticide) & $\mathrm{kg}$ & 0.018 & 0.018 & 0.018 & 0.018 & 0.018 & 0.018 & 0.036 \\
\hline Chlorantraniliplore (insecticide) & $\mathrm{kg}$ & 0.2 & 0.2 & 0.2 & 0.2 & 0.2 & 0.2 & 0 \\
\hline Bacillus-Thuringiensis (insecticide) & $\mathrm{kg}$ & 0.16 & 0.16 & 0.16 & 0.16 & 0.16 & 0.16 & 0 \\
\hline Tebuconazol (fungicide) & $\mathrm{kg}$ & 0.2 & 0.2 & 0.2 & 0.2 & 0.2 & 0.2 & 0.6 \\
\hline Trifloxistrobine (fungicide) & $\mathrm{kg}$ & 0.1 & 0.1 & 0.1 & 0.1 & 0.1 & 0.1 & 0 \\
\hline Metalaxyl-m (fungicide) & $\mathrm{kg}$ & 0.04 & 0.04 & 0.04 & 0.04 & 0.04 & 0.04 & 0 \\
\hline Mancozeb (fungicide) & $\mathrm{kg}$ & 0.64 & 0.64 & 0.64 & 0.64 & 0.64 & 0.64 & 0 \\
\hline Ancozeb (fungicide) & $\mathrm{kg}$ & 3.2 & 3.2 & 3.2 & 3.2 & 3.2 & 3.2 & 0 \\
\hline Thiabendazole (fungicide) & $\mathrm{kg}$ & 0.1 & 0.1 & 0.1 & 0.1 & 0.1 & 0.1 & 0 \\
\hline Casugamicine (fungicide) & $\mathrm{kg}$ & 0.01 & 0.01 & 0.01 & 0.01 & 0.01 & 0.01 & 0 \\
\hline Sulfur (fungicide) & $\mathrm{kg}$ & 2.6 & 2.6 & 2.6 & 2.6 & 2.6 & 2.6 & 0 \\
\hline Ciromazine (insecticide) & $\mathrm{kg}$ & 0 & 0 & 0 & 0 & 0 & 0 & 0.36 \\
\hline Tiaclopride (insecticide) & $\mathrm{kg}$ & 0 & 0 & 0 & 0 & 0 & 0 & 0.48 \\
\hline Tiofanato-Metílico (fungicide) & $\mathrm{kg}$ & 0 & 0 & 0 & 0 & 0 & 0 & 0.6 \\
\hline Clorotalonil (fungicide) & $\mathrm{kg}$ & 0 & 0 & 0 & 0 & 0 & 0 & 1.5 \\
\hline Tetraconazole (fungicide) & $\mathrm{kg}$ & 0 & 0 & 0 & 0 & 0 & 0 & 0.3 \\
\hline Cimoxanil (fungicide) & $\mathrm{kg}$ & 0 & 0 & 0 & 0 & 0 & 0 & 0.18 \\
\hline Famoxadone (fungicide) & $\mathrm{kg}$ & 0 & 0 & 0 & 0 & 0 & 0 & 0.14 \\
\hline Difeconazol (fungicide) & $\mathrm{kg}$ & 0 & 0 & 0 & 0 & 0 & 0 & 0.25 \\
\hline Trifumizole (fungicide) & $\mathrm{kg}$ & 0 & 0 & 0 & 0 & 0 & 0 & 0.6 \\
\hline Nonifenol-Etoxilado (dispersant) & $\mathrm{kg}$ & 0 & 0 & 0 & 0 & 0 & 0 & 0.25 \\
\hline Emissions & & & & & & & & \\
\hline Residue $^{\mathrm{b}}$ & $\mathrm{kg}$ & 26.85 & 26.85 & 26.85 & 26.85 & 26.85 & 26.85 & 65.18 \\
\hline $\mathrm{CO}_{2}$ & $\mathrm{~kg}$ & 2543.55 & 2888.17 & 2890.08 & 3213.83 & 3221.051 & 3608.765 & 5001.15 \\
\hline $\mathrm{CH}_{4}$ & $\mathrm{~kg}$ & 1.003 & 1.003 & 1.003 & 1.006 & 1.006 & 1.006 & 0.974 \\
\hline $\mathrm{CO}$ & $\mathrm{kg}$ & 27.43 & 27.43 & 27.43 & 27.43 & 27.43 & 27.43 & 27.43 \\
\hline $\mathrm{N}_{2} \mathrm{O}$ & $\mathrm{kg}$ & 6.56 & 6.349 & 5.126 & 6.775 & 6.751 & 5.221 & 8.006 \\
\hline $\mathrm{NH}_{3}$ & $\mathrm{~kg}$ & 18.68 & 18.68 & 18.68 & 18.68 & 18.68 & 18.68 & 6.776 \\
\hline NOx & $\mathrm{kg}$ & 3.01 & 2.96 & 2.71 & 3.05 & 3.04 & 2.72 & 3.28 \\
\hline $\mathrm{NO}_{3}^{-}$ & $\mathrm{kg}$ & -71.93 & -61.16 & -19.61 & -74.54 & -76.23 & -23.49 & 84.55 \\
\hline $\mathrm{PO}^{3-}$ & $\mathrm{kg}$ & 0.284 & 0.284 & 0.284 & 0.284 & 0.284 & 0.284 & 0.306 \\
\hline $\mathrm{P}$ & $\mathrm{kg}$ & 0.005 & 0.005 & 0.005 & 0.005 & 0.005 & 0.005 & 0.018 \\
\hline $\mathrm{Cd}$ & $\mathrm{mg}$ & 3.31 & 3.31 & 3.31 & 3.31 & 3.31 & 3.31 & 3.34 \\
\hline $\mathrm{Cu}$ & $\mathrm{mg}$ & -4.36 & -4.36 & -4.36 & -4.36 & -4.36 & -4.36 & $120,660.18$ \\
\hline $\mathrm{Zn}$ & $\mathrm{mg}$ & 7.41 & 7.41 & 7.41 & 7.41 & 7.41 & 7.41 & $187,924.68$ \\
\hline $\mathrm{Pb}$ & $\mathrm{mg}$ & 0.208 & 0.208 & 0.208 & 0.208 & 0.208 & 0.208 & 0.28 \\
\hline $\mathrm{Ni}$ & $\mathrm{mg}$ & 2.66 & 2.66 & 2.66 & 2.66 & 2.66 & 2.66 & 3.53 \\
\hline $\mathrm{Cr}$ & $\mathrm{mg}$ & -345.8 & -345.8 & -345.8 & -345.8 & -345.8 & -345.8 & -364.68 \\
\hline Pesticides & & & & & & & & \\
\hline Thiamethoxam (insecticide) & $\mathrm{kg}$ & 0.175 & 0.175 & 0.175 & 0.175 & 0.175 & 0.175 & 0.25 \\
\hline Methomil (insecticide) & $\mathrm{kg}$ & 0.645 & 0.645 & 0.645 & 0.645 & 0.645 & 0.645 & 0.645 \\
\hline Abamectin (insecticide) & $\mathrm{kg}$ & 0.018 & 0.018 & 0.018 & 0.018 & 0.018 & 0.018 & 0.036 \\
\hline Chlorantraniliplore (insecticide) & $\mathrm{kg}$ & 0.2 & 0.2 & 0.2 & 0.2 & 0.2 & 0.2 & 0 \\
\hline Bacillus-Thuringiensis (insecticide) & $\mathrm{kg}$ & 0.16 & 0.16 & 0.16 & 0.16 & 0.16 & 0.16 & 0 \\
\hline Tebuconazol (fungicide) & $\mathrm{kg}$ & 0.2 & 0.2 & 0.2 & 0.2 & 0.2 & 0.2 & 0.6 \\
\hline Trifloxistrobine (fungicide) & $\mathrm{kg}$ & 0.1 & 0.1 & 0.1 & 0.1 & 0.1 & 0.1 & 0 \\
\hline Metalaxyl-m (fungicide) & $\mathrm{kg}$ & 0.04 & 0.04 & 0.04 & 0.04 & 0.04 & 0.04 & 0 \\
\hline Mancozeb (fungicide) & $\mathrm{kg}$ & 0.64 & 0.64 & 0.64 & 0.64 & 0.64 & 0.64 & 0 \\
\hline
\end{tabular}


Table 2 (continued)

\begin{tabular}{|c|c|c|c|c|c|c|c|c|}
\hline \multirow[t]{2}{*}{ Inventory } & \multirow[t]{2}{*}{ Unit } & \multicolumn{6}{|c|}{ Melon production in conservationist system } & \multirow{2}{*}{$\begin{array}{l}\text { Melon production in } \\
\text { conventional system }\end{array}$} \\
\hline & & Treatment $1^{\mathrm{a}}$ & Treatment $2^{a}$ & Treatment $3^{a}$ & Treatment $4^{a}$ & Treatment $5^{\mathrm{a}}$ & Treatment $6^{\mathrm{a}}$ & \\
\hline Ancozeb (fungicide) & $\mathrm{kg}$ & 3.2 & 3.2 & 3.2 & 3.2 & 3.2 & 3.2 & 0 \\
\hline Thiabendazole (fungicide) & $\mathrm{kg}$ & 0.1 & 0.1 & 0.1 & 0.1 & 0.1 & 0.1 & 0 \\
\hline Casugamicine (fungicide) & $\mathrm{kg}$ & 0.01 & 0.01 & 0.01 & 0.01 & 0.01 & 0.01 & 0 \\
\hline Sulfur (fungicide) & $\mathrm{kg}$ & 2.6 & 2.6 & 2.6 & 2.6 & 2.6 & 2.6 & 0 \\
\hline Ciromazine (insecticide) & $\mathrm{kg}$ & 0 & 0 & 0 & 0 & 0 & 0 & 0.36 \\
\hline Tiaclopride (insecticide) & $\mathrm{kg}$ & 0 & 0 & 0 & 0 & 0 & 0 & 0.48 \\
\hline Tiofanato-Metílico (fungicide) & $\mathrm{kg}$ & 0 & 0 & 0 & 0 & 0 & 0 & 0.6 \\
\hline Clorotalonil (fungicide) & $\mathrm{kg}$ & 0 & 0 & 0 & 0 & 0 & 0 & 1.5 \\
\hline Tetraconazole (fungicide) & $\mathrm{kg}$ & 0 & 0 & 0 & 0 & 0 & 0 & 0.3 \\
\hline Cimoxanil (fungicide) & $\mathrm{kg}$ & 0 & 0 & 0 & 0 & 0 & 0 & 0.18 \\
\hline Famoxadone (fungicide) & $\mathrm{kg}$ & 0 & 0 & 0 & 0 & 0 & 0 & 0.14 \\
\hline Difeconazol (fungicide) & $\mathrm{kg}$ & 0 & 0 & 0 & 0 & 0 & 0 & 0.25 \\
\hline Trifumizole (fungicide) & $\mathrm{kg}$ & 0 & 0 & 0 & 0 & 0 & 0 & 0.6 \\
\hline Nonifenol-Etoxilado (dispersant) & $\mathrm{kg}$ & 0 & 0 & 0 & 0 & 0 & 0 & 0.25 \\
\hline
\end{tabular}

${ }^{\text {a }}$ Refer to Table 1 for detailed listing of the six treatments.

b Residue refers to irrigation plastic tubes and mulch used in the processes. Fertilizers and pesticides packaging residue were not included.

Table 3

Gross irrigation water requirement (GIWR) for melon cultivated in the São Francisco Valley.

\begin{tabular}{lllll}
\hline Year & $\begin{array}{l}\text { ETo }^{\mathrm{a}} \\
\text { Average value } \\
\left(\mathrm{mm}_{\text {day }}{ }^{-1}\right)\end{array}$ & $\begin{array}{l}\mathrm{ETp}^{\mathrm{a}} \\
\text { Average value } \\
\left(\mathrm{mm}_{\text {.day }}{ }^{-1}\right)\end{array}$ & $\begin{array}{l}\text { Irrigation } \\
\text { Efficiency }\end{array}$ & $\begin{array}{l}\text { GIWR } \\
\text { Average } \\
\text { value } \\
(\mathrm{mm} / \\
\text { cycle) }\end{array}$ \\
\hline 2011 & 5.64 & 3.80 & & 263.29 \\
2012 & 6.03 & 3.28 & 0.85 & 163.48 \\
2013 & 6.04 & 3.93 & 0.85 & 273.18 \\
2014 & 5.78 & 3.67 & 0.85 & 241.47 \\
2015 & 5.62 & 3.64 & 0.85 & 256.37 \\
2016 & 6.00 & 4.08 & 0.85 & 335.41 \\
Average & & 0.85 & $\mathbf{2 5 5 . 5 3}$ \\
\hline
\end{tabular}

${ }^{a}$ ETo - daily reference evapotranspiration; ETc - evapotranspiration.

energy, fertilizers and pesticides, while the quantity of green manure biomass produced, diesel consumed, and melon yields varied. Treatments 1 and 4 used the same mass of seeds, which differed from treatments 2 and 5. Treatments 3 and 6 did not use seeds, but instead allowed spontaneous vegetation growth. Regarding diesel needs, treatments 3, 4, and 6 required more fuel than treatments 1,2 , and 3 to incorporate the green manure biomass into the soil.

Considering years 2011-2016, the average quantity of melons produced from treatment 5 was the highest compared to the other treatments.

Emissions were also higher in the conventional system compared to the conservationist system, except for ammonia. More ammonia was generated because urea (not used in the conventional system) was the nitrogen fertilizer used the most in the conservationist system. Regarding pesticides, different active ingredients were applied in the conventional and conservationist systems. The conservationist system was less disturbed by insects, but was more affected by fungus than the conventional system.

The green manure biomass in the conservationist systems removed more carbon from the air, and nitrogen and micronutrients (copper) from the soil. When the biomass was cut and left on top of the soil, there was an increase in soil organic matter, and consequently, carbon stocks, especially in treatment T1. More detail about the carbon storage in soil as well as the sources of each GHG during melon production, for the conservationist and conventional systems, is in Appendix C (Supplementary material).

The nitrogen required by green manure plants, especially in treatment 5, and melons was higher than the nitrogen supplied to the system, resulting in negative nitrate emission values. The conventional system, based solely on melon production, required lower nitrogen and micronutrients than the amount supplied, resulting in higher emissions to air, soil and water.

The negative values for chromium $(\mathrm{Cr})$ in Table 2 for both analyzed systems was mainly due to the low input of this metal in the applied fertilizers and the high fixed amount of leached chromium considered in this study $(21,200 \mathrm{mg} / \mathrm{ha}$ per year). This value was fixed by Nemecek and Schnetzer (2012) for Europe, and was adopted for this study in the absence of regional data for Brazil.

\subsection{Impact assessment}

Melons produced in the conventional system adopted by farmers in the São Francisco Valley resulted in higher environmental impacts than those produced in the conservationist system for all impact categories and treatments evaluated (Fig. 2). The lowest impacts occurred from the conservationist treatment 5 (T5). The treatments generally followed the same pattern in most impact categories because they used similar quantities of most of the inputs.

The differences observed between the treatments in the impact for marine eutrophication were mainly due to varying yields and stocks of nitrogen in the soil organic matter. The treatments based on seed cocktails of leguminous and non-leguminous plants (T1, T2, T4, and T5) required more nitrate from soil to grow both green manure and melon crops, which lead to lower nitrate emissions and impacts in marine eutrophication (Fig. 3).

Regarding water depletion, it is important to note that the volume of irrigation water applied by farmers was higher than the volume used in the experimental area. This occurred because the volume applied in the experimental area was based on the measuring of evapotranspiration, precipitation, and consideration of the culture coefficient (kc) at each production stage. Conversely, farmers' use of irrigation water in the conventional system was above the culture need, leading to higher impact in water depletion in a semi-arid region that has water shortages most of the year.

The uncertainty analysis for the comparison of the conventional and conservationist systems (treatment 5 , with the lowest average impacts) showed that the conventional system caused significantly higher impacts on climate change, marine eutrophication, water depletion, human non-cancer toxicity, and freshwater ecotoxicity (Table 4). Furthermore, the comparison of treatments 1, 2, 3, 4, and 6 with the conventional system also revealed better performance 


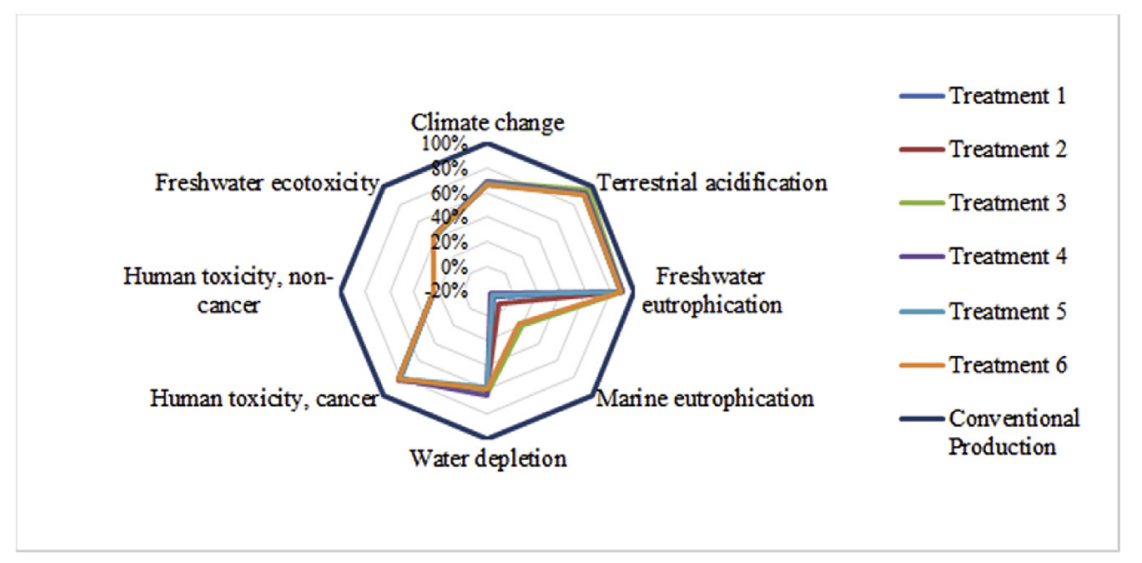

Fig. 2. Environmental impacts of conventional and conservationist systems.

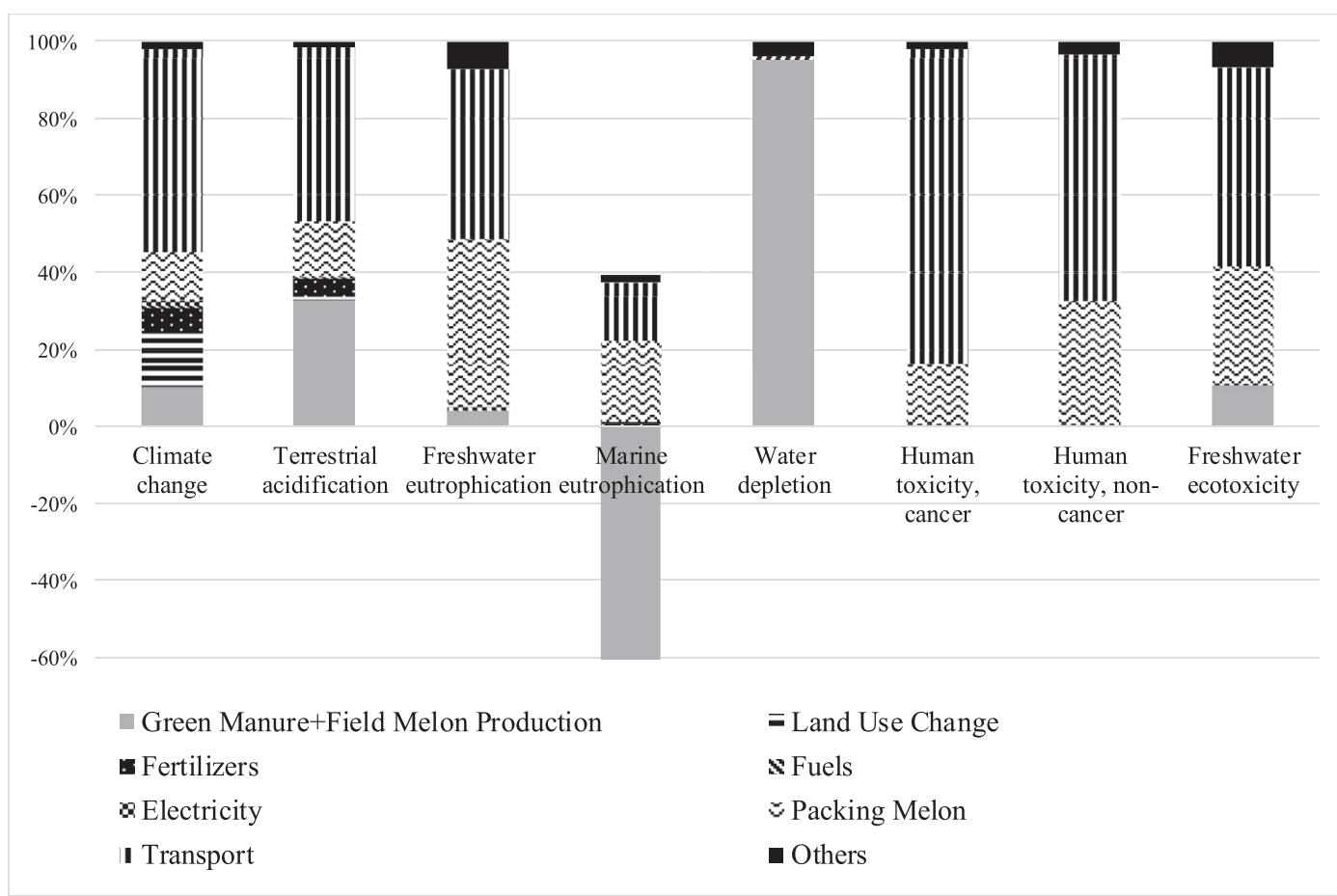

Fig. 3. Contribution analysis for conservationist treatment 5.

for the conservationist system for all treatments (Appendix D in the Supplementary material).

The main processes contributing to the environmental impacts of melons produced in the conservationist treatments were fruit transportation, packing, and field production (Fig. 3). The high consumption of fuel by trucks to distribute melons in the Brazilian southeast regions was a major source of these impacts. During highway transportation, fuel burning resulted in nitrogen and sulfur emissions, and was responsible for considerable impacts on climate change, acidification, and toxicity. The production of cardboard boxes for melon packaging was the most important impact source on marine and freshwater eutrophication. Regarding melon production, the emissions of ammonia from fertilization and sulfur oxides from diesel burning by farm equipment caused acidification. The practice of green manure before melon production contributes positively to reduce the impacts on eutrophication. Water used for melon irrigation was the main contributor for water depletion.

\subsection{Scenario analysis}

Considering the main processes responsible for the environmental impacts in the conservationist system, alternative scenarios for transportation, packaging, and fertilization were defined. Discussions with researchers and producers in the São Francisco Valley showed the feasibility of the following proposed scenarios: 1) for transportation, combination of maritime with terrestrial melon transportation; 2) for packaging, substitution of cardboard for plastic boxes for melon packing; and 3) for fertilization, reduction of nitrogen from synthetic fertilizers, considering the nitrogen content available in the green manure biomass. The scenarios (1, 2 and 3 ) that generated reduction in all categories of environmental impacts were then combined and evaluated in scenario 4 .

Some considerations were made to build scenarios 1, 2, and 3. In scenario 1, it was assumed that melons are transported from Petrolina city (São Francisco Valley) to the Salvador port (Bahia) by 
Table 4

Comparison between the conventional system and the conservationist treatment 5 for 1 ton of melon produced.

\begin{tabular}{|c|c|c|c|c|}
\hline Impact Category & Unit & Conventional system & Conservationist treatment $5^{\mathrm{a}}$ & Conventional System $>$ Conservationist treatment 5 \\
\hline Climate change & $\mathrm{kg} \mathrm{CO} 2$ eq & 754.11 & 515.09 & $96.80 \%$ \\
\hline Terrestrial acidification & $\mathrm{kg} \mathrm{SO}_{2}$ eq & 3.78 & 3.45 & $68.20 \%$ \\
\hline Freshwater eutrophication & $\mathrm{kg} P$ eq & 0.069 & 0.059 & $76.60 \%$ \\
\hline Marine eutrophication & $\mathrm{kg} \mathrm{N}$ eq & 0.895 & -0.136 & $100 \%$ \\
\hline Water depletion & $\mathrm{m}^{3}$ & 268.91 & 156.49 & $100 \%$ \\
\hline Human toxicity, cancer & CTUh & $2.50 \mathrm{E}-05$ & $2.04 \mathrm{E}-05$ & $73.90 \%$ \\
\hline Human toxicity, non-cancer & CTUh & $3.34 \mathrm{E}-04$ & $7.79 \mathrm{E}-05$ & $97.80 \%$ \\
\hline Freshwater ecotoxicity & CTUe & 5144.99 & 2127.72 & $99.90 \%$ \\
\hline
\end{tabular}

${ }^{a}$ Treatment 5: Green manure with seed cocktail 2 (25\% legumes $+75 \%$ non-legumes) + Cutting of green manure biomass with tillage + melon production.

closed trucks (20-ton capacity), and then to the Santos port (São Paulo) by ship, and from there onto the São Paulo distribution market by closed truck (20-ton capacity). In scenario 2, the plastic boxes are made of high-density polyethylene, assumed to have the same capacity as the cardboard boxes (30 kg), and only used once (as is currently done), rather than being returned to the farmers. In scenario 3, according to laboratorial analysis, the mass of nitrogen provided by green fertilizers in treatment 5 was $172.66 \mathrm{~kg} / \mathrm{ha}$. This nitrogen present in green manure biomass is considered to surpass the nitrogen needs of melons $(107.4 \mathrm{~kg} / \mathrm{ha})$. Throughout the melon production cycle and cultivation years, stability in the crop system related to the degradation of biomass and the supply of nutrients for cultivation was anticipated in accordance with Singogo et al. (1996) and Braz et al. (2006).
The analysis of these scenarios showed that the greater reduction in impacts occurred when maritime and terrestrial transportation were combined, and the reduction of synthetic fertilizer took place (scenario 4 in Fig. 4). Conversely, changing paperboard for plastic box led to higher impacts on climate change and human toxicity-cancer (scenario 2 in Fig. 4), due to the process of petrol refining to obtain polyethylene. This process generates emissions of $\mathrm{NH}_{3}, \mathrm{CO}_{2}, \mathrm{NO}_{\mathrm{x}}, \mathrm{CO}, \mathrm{H}_{2} \mathrm{~S}, \mathrm{SO}_{\mathrm{x}}$, heavy metals, acids and volatile organic compounds (VOCs), among other toxic substances.

The comparison of scenarios 1,3 , and 4 with the conservationist treatment 5 shows that all impact category values are reduced. Although farmers could quickly implement the transportation route proposed in scenario 1 , the reduction of synthetic nitrogen fertilizer, proposed in treatment 5 (scenario 3 ), should be tested in a

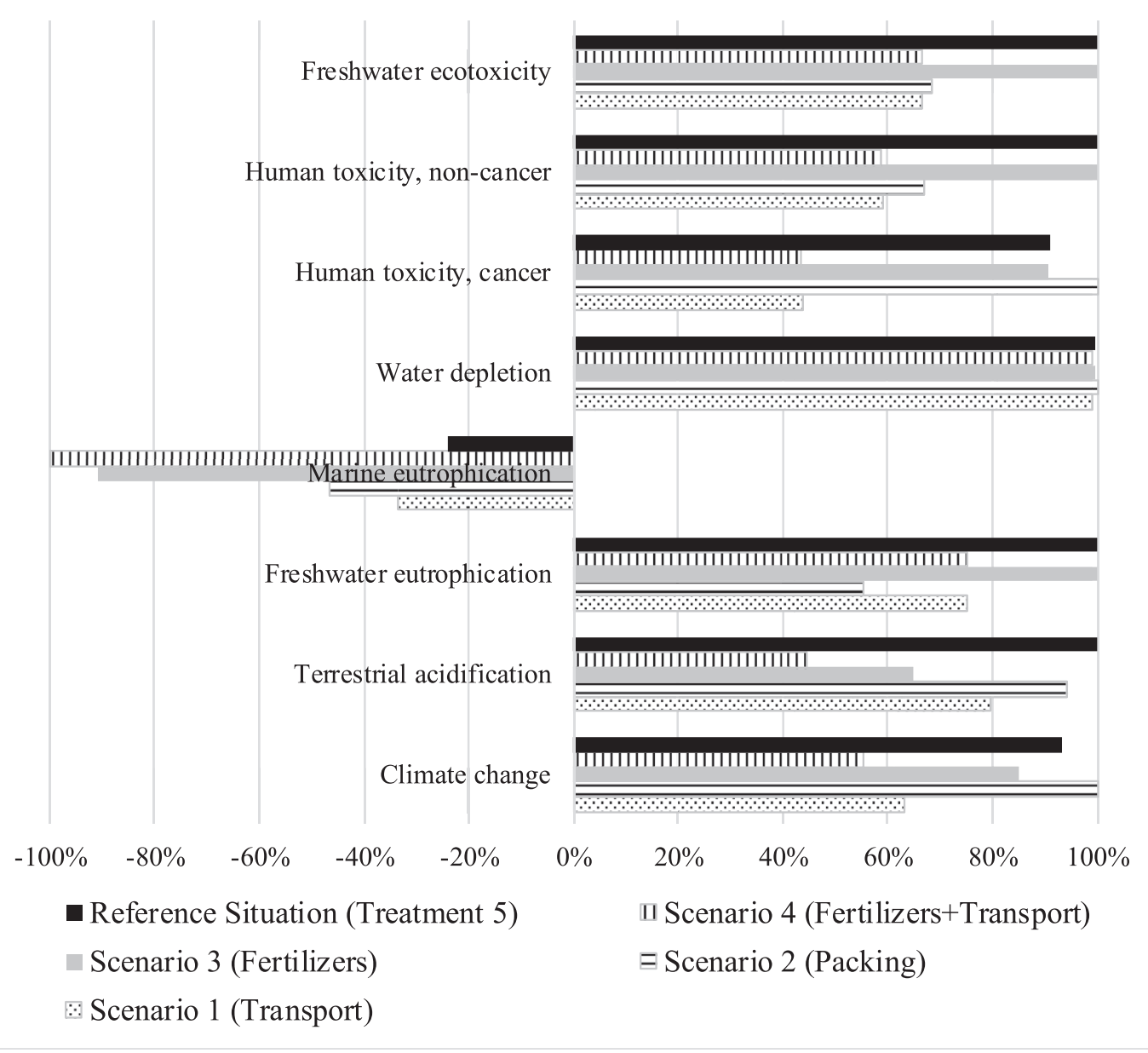

Fig. 4. Scenarios analysis for conservationist treatment 5. 
pilot area to ensure melon yield would not change.

\subsection{Economic analysis}

The analysis of profits from both best conservationist (treatment 5 ) and conventional systems shows that treatment 5 results in higher profit than the conventional system (Table 5). Although costs in treatment 5 are higher than in the conventional system, the yield is also higher, offsetting costs. The higher costs in treatment 5 are due to the use of seedlings ( $28 \%$ of total cost), instead of seeds, cocktail seeds ( $26 \%$ of total cost). The conventional system presents higher service costs related to subsoiling, soil grooving, laying of mulch, and foundation fertilization.

\section{Discussion}

This study showed that conservationist treatment 5 , based on green manure tillage (biomass incorporation into the soil), reduced

Table 5

Production cost of the conventional and conservationist (Treatment 5) systems.

\begin{tabular}{|c|c|c|c|c|}
\hline \multicolumn{5}{|c|}{ Production cost of 1 ha of melon in Conventional System } \\
\hline Specification & Unit & Amount & Total (U\$) & Participation (\%) \\
\hline Services & & & 1601.48 & 28.51 \\
\hline Subsoiling & $\mathrm{MH}^{\mathrm{a}}$ & 6.00 & 194.40 & 3.46 \\
\hline Plowing/Grading & $\mathrm{MH}$ & 3.00 & 97.20 & 1.73 \\
\hline Surfing/Slab & $\mathrm{MH}$ & 4.00 & 129.60 & 2.31 \\
\hline Mulch placement & $\mathrm{MH}$ & 3.00 & 97.20 & 1.73 \\
\hline Foundation fertilization & $\mathrm{DM}^{\mathrm{b}}$ & 10.00 & 138.86 & 2.47 \\
\hline Planting/Replanting & $\mathrm{DM}$ & 8.00 & 111.09 & 1.98 \\
\hline Spraying & DM & 11.00 & 152.74 & 2.72 \\
\hline Irrigation & DM & 4.00 & 55.54 & 0.99 \\
\hline Harvest/classification & DM & 45.00 & 624.85 & 11.12 \\
\hline Inputs & & & 4016.00 & 71.49 \\
\hline Melon Seeds & unit & 16.70 & 1082.15 & 19.26 \\
\hline Mulch & $\mathrm{m}$ & 0.30 & 694.28 & 12.36 \\
\hline Manure & $\mathrm{m}^{3}$ & 20.00 & 370.28 & 6.59 \\
\hline Fertilizers & $\mathrm{kg}$ or $\mathrm{L}$ & 928.00 & 867.20 & 15.44 \\
\hline Insecticide & $\mathrm{kg}$ or $\mathrm{L}$ & 4.48 & 494.79 & 8.81 \\
\hline Fungicide & $\mathrm{kg}$ or $\mathrm{L}$ & 12.60 & 376.76 & 6.71 \\
\hline Spreader & $\mathrm{L}$ & 1.00 & 5.55 & 0.10 \\
\hline Water & $1,000 \mathrm{~m}^{3}$ & 9.00 & 124.97 & 2.22 \\
\hline Total cost & & & 5617.48 & 100 \\
\hline Total Revenue & & & $20,668.47$ & \\
\hline Profit (Revenue - Cost) & & & $\underline{15,050.99}$ & \\
\hline
\end{tabular}

Production cost of 1 ha of melon in Treatment 5

\begin{tabular}{|c|c|c|c|c|}
\hline Specification & Unit & Amount & Total (U\$) & Participation (\%) \\
\hline Services & & & 1041.42 & 17.67 \\
\hline Plowing/Grading & MH & 3.00 & 97.20 & 1.65 \\
\hline Planting/Replanting & $\mathrm{DM}$ & 8.00 & 111.09 & 1.88 \\
\hline Spraying & DM & 11.00 & 152.74 & 2.59 \\
\hline Irrigation & $\mathrm{DM}$ & 4.00 & 55.54 & 0.94 \\
\hline Harvest/classification & DM & 45.00 & 624.85 & 10.60 \\
\hline Inputs & & & 4853.29 & 82.33 \\
\hline Melon Seedling & unit & $12,500.00$ & 1677.85 & 28.46 \\
\hline Bean seeds & $\mathrm{kg}$ & 161.75 & 914.87 & 15.52 \\
\hline Maize seeds & $\mathrm{kg}$ & 157.87 & 615.99 & 10.45 \\
\hline Fertilizers & $\mathrm{kg}$ or L & 605.00 & 855.89 & 14.52 \\
\hline Insecticide & $\mathrm{kg}$ or $\mathrm{L}$ & 6.70 & 468.64 & 7.95 \\
\hline Fungicide & $\mathrm{kg}$ or $\mathrm{L}$ & 16.00 & 230.23 & 3.91 \\
\hline Acaricide & $\mathrm{kg}$ & 0.50 & 5.26 & 0.09 \\
\hline Water & $1,000 \mathrm{~m}^{3}$ & 6.09 & 84.57 & 1.43 \\
\hline Total cost & & & 5894.72 & 100 \\
\hline Total Revenue & & & $25,126.46$ & \\
\hline Profit (Revenue - Cost) & & & $\underline{19,231.75}$ & \\
\hline
\end{tabular}

a Machine Hour.

b Day Men. environmental impacts and increased the profit obtained from melon commercialization. This was mainly because of the higher yields achieved in this treatment. Moreover, it also showed that there was no meaningful difference among the conservationist treatments in terms of environmental impacts. At this point, the two following questions are of importance for producers interested in improving the environmental performance of melons: Which conservationist treatment should be chosen? Are there other melon production systems available resulting in lower impacts than the one ones observed for the conservationist system in this study?

\subsection{Decision regarding which conservationist treatment to adopt}

Treatments 4, 5, and 6 presented superior performances in the short-term because biomass incorporation allowed the soil microorganisms' rapid contact with the biomass, enhancing decomposition reactions and nutrient liberation for melon plant growth. Conversely, when the green manure biomass was not tilled, the decomposition process and nutrient liberation is slower, occurring in medium and long-term timeframes according to Ambrosano et al. (2005), Calegari (2014), and Peche Filho et al. (2014). In the untilled case, higher availability of nutrients is expected to occur in the long-term.

When analyzing the yield growth percentages from 2011 to 2016, treatments 1 and 2 (no-tillage) showed higher melon yield over time than treatments 4 and 5 (Table 6 ). It is possible that in the medium-term (around 8 to ten years after the practice of green manure is applied), treatment 2 present equal or higher yields than treatment 5, causing lower environmental impacts per ton of melon produced. Another important aspect is that by not tilling, soil carbon storage may increase, erosion rates decrease, and water use decline because of reduced soil evaporation (Teófilo et al., 2012). Thus, it is recommended that treatment 2 be further investigated without the application of a synthetic nitrogen fertilizer, along with treatment 5 , to evaluate if melon yields keep high.

\subsection{Comparison with other studies}

When investigating the literature regarding the environmental impacts of melon production, it was observed that most studies focused on conventional melon production systems (Cellura et al., 2012; Figueirêdo et al., 2013, 2014a). Furthermore, the Brazilian studies focused in the categories of climate change and water use (Figueirêdo et al., 2013, 2014a). The impact values indicated in these previous studies were all superior to the ones found in this work for the conservationist treatment 5 .

Cellura et al. (2012) evaluated the carbon footprint (i.e., impact on climate change) of Sicilian melons produced in Italian greenhouses. The authors reported a melon carbon footprint of $1427 \mathrm{~kg}$ $\mathrm{CO} 2-\mathrm{eq} / \mathrm{t}$, which was higher than the value found in this study $(515 \mathrm{~kg} \mathrm{CO}-\mathrm{eq} / \mathrm{t}$ for the conservationist treatment 5 and $754 \mathrm{~kg}$ $\mathrm{CO} 2-\mathrm{eq} / \mathrm{t}$ for the conventional system). The higher values found by Cellura et al. (2012) could be from the differences in the method used to estimate greenhouse gases (GHG) emissions and the production system that in Italy occurs in greenhouses instead of open fields.

In Brazil, Figueirêdo et al. (2013) assessed the impact of melons on the carbon footprint ( $710 \mathrm{~kg} \mathrm{CO} 2-\mathrm{eq} / \mathrm{t}$ of melon), and Figueirêdo et al. (2014a), on water scarcity $\left(135 \mathrm{~m}^{3} \mathrm{H} 2 \mathrm{O}-\mathrm{eq} / \mathrm{t}\right.$ of melon, with a water consumption of $198 \mathrm{~m}^{3} / \mathrm{t}$ of melon). In both studies, melons were cultivated by conventional methods in the Low Jaguaribe and Açu region. The comparison of results from this study with those from Figueirêdo et al. (2013) shows that melons produced by the conservationist treatment 5 cause a lower impact on climate 
Table 6

Melon yields over time in the conservationist system.

\begin{tabular}{|c|c|c|c|c|c|c|}
\hline $\begin{array}{l}\text { Treatment/yield } \\
(\mathrm{kg} / \mathrm{ha})\end{array}$ & Treatment $1^{\mathrm{a}}$ & Treatment $2^{a}$ & Treatment $3^{a}$ & Treatment $4^{\mathrm{a}}$ & Treatment $5^{\mathrm{a}}$ & Treatment $6^{a}$ \\
\hline 2011 & $20,243.1$ & $21,076.4$ & 21.201 .4 & $26,625.0$ & $30,638.9$ & $24,041.6$ \\
\hline 2012 & $21,632.5$ & $24,575.0$ & 22.960 .0 & $26,395.0$ & $25,137.5$ & $26,570.0$ \\
\hline 2013 & $37,447.9$ & $42,989.6$ & 32.791 .7 & $50,697.9$ & $41,120.8$ & $44,260.4$ \\
\hline 2014 & $49,862.5$ & $46,162.5$ & 37.462 .5 & $51,512.5$ & $50,762.5$ & $49,200.8$ \\
\hline 2015 & $39,412.5$ & $40,187.5$ & 31.287 .5 & $28,662.5$ & $31,125.0$ & $33,087.5$ \\
\hline 2016 & $65,283.7$ & $72,968.0$ & 69.414 .9 & $56,085.7$ & $60,289.0$ & $51,700.5$ \\
\hline Average & $40,533.3$ & $39,773.6$ & 35.853 .0 & $38,859.7$ & $40,982.4$ & $38,143.5$ \\
\hline \multicolumn{7}{|l|}{ Growth rate } \\
\hline $2011 / 2016$ & $210 \%$ & $260 \%$ & $227 \%$ & $83 \%$ & $126 \%$ & $115 \%$ \\
\hline
\end{tabular}

${ }^{\text {a }}$ Refer to Table 1 for details of the six treatments.

change, mainly due to the higher yields and lower use of nitrogen fertilizer. Regarding water scarcity, the water depletion method used by Figueirêdo et al. (2014a) differed from the one applied in this study, and therefore impact results could not be directly compared. Nonetheless, considering only the water productivity, the consumption in treatment $5\left(148 \mathrm{~m}^{3} / \mathrm{t}\right.$ of melon) was lower than the one reported by Figueirêdo et al. (2014a), mainly because the overuse of irrigation water in melon farms in the Low Jaguaribe and Açu region. This study also showed that irrigation water is also overused by melon farms of the conventional system in the São Francisco Valley, being necessary the capacitation of melon farmers in the topic of efficient irrigation practices, in both melon production regions.

\section{Conclusions}

Melon production in a conservationist system based on green manure resulted in higher yields than in the conventional system, reduced the environmental impacts in all considered categories, and led to higher profit. Among the conservationist treatments evaluated in this study, the one based on a combination of $25 \%$ legume and $75 \%$ non-legume seeds, in conjunction with tilling the green manure biomass before melon production (treatment 5) resulted in the smallest environmental impacts. Nonetheless, any one of the conservationist treatments will equally reduce the impacts compared to the conventional system.

Considering treatment 5 , the scenario analysis showed that the impacts of all categories could be lowered when the maritime and terrestrial transportation of melons are combined, and the use of synthetic fertilizer in plant production is reduced. It is expected that melon yield will be maintained if the only source of nitrogen is from green manure, since it meets the total nitrogen demand of the melon plant. Incorporating green manure biomass into the soil or leaving it on the soil surface were both considered good practices, depending on the time period. Biomass incorporation lead to higher yields in the short-term, while the no-tillage practice is more promising for the long-term.

This study recommends that melon transportation in Brazil use a terrestrial and maritime route, and that melon farms start to intercrop melon production with green manure based on seed cocktail. It also suggests that a pilot area be settled to ensure yield is not reduced when melons are produced under the conservationist system, and without applying synthetic nitrogen fertilization.

\section{Acknowledgement}

The National Council of Scientific and Technological Development $(\mathrm{CNPq})$ and The Brazilian Agriculture Research Corporation (Embrapa) supported this work.

\section{Appendix A. Supplementary data}

Supplementary data related to this article can be found at https://doi.org/10.1016/j.jclepro.2017.12.266.

\section{References}

APEX Brazil, 2015. Profile of Brazilian Melons Exports in 2014 (Perfil Exportador Dos Melões Brasileiros em 2014). Agência Brasileira de Promoção de Exportações e Investimentos. $\quad$ http://www.apexbrasil.com.br/Noticia/APEX-BRASIL-EABRAFRUTAS-ASSINAM-CONVENIO-PARA-EXPORTACAO-DE-FRUTASBRASILEIRAS.

Ambrosano, E.J., Guirado, N., Cantarella, H., Rossetto, R., Mendes, P.C., Rossi, F., 2005. Plantas Para Cobertura do Solo e Adubação Verde Aplicadas ao Plantio Direto. Informações Agronômicas. No. 112, 2005. http://www.ipni.net/PUBLICATION/ IA-BRASIL.NSF/0/30D47AFEEFB8D57283257AA1006AD718/\$FILE/Encarte112. pdf.

Baggs, E.M. Watson, C.A., Rees, R.M., 2000. The fate of nitrogen from incorporated cover crop and green manure residues. Nutrient Cycl. Agroecosyst. 56, 153-163.

Bayer, C., Lovato, T., Diekow, J., Zanatta, J.A., Mielniczuk, J., 2006. A method for estimating coefficients of soil organic matter dynamics based on long-term experiments. Soil Tillage Res. 91, 217-236.

Braga, M.B., 2016. Irrigação (Irrigation). In: Costa, N.D. (Ed.), Sistema de Produção do Melão [Melon production system]. ISSN: 1807-0027. https://www.spo.cnptia. embrapa.br.

Braz, A.J.B.P., Silveira, P.M., Kliemann, H.M., Zimmermann, J.P., 2006. Nitrogen fertilization of wheat grown under no-tillage after different cover crops. Cienc. E Agrotecnol. 30, 193-198. http://www.scielo.br/pdf/cagro/v30n2/v30n2a01. pdf.

Calegari, A., 2014. Perspectives and strategies for the sustainability and increase in biodiversity of crop systems applying green manure (Perspectivas e estratégias para a sustentabilidade e o aumento da biodiversidade dos sistemas agrícolas com uso de adubos verdes). In: Lima Filho, O.F., Ambrosano, E.J., Rossi, F., Carlos, J.A.D. (Eds.), Green manure and cover plants in Brazil (Adubação verde e plantas de cobertura no Brasil). EMBRAPA, Brasília, pp. 265-305. Fundamentos e Prática, v. 1 .

Cellura, M., Longo, S., Mistretta, M., 2012. Life cycle assessment (LCA) of protected crops: an Italian case study. J. Clean. Prod. 28, 56-62.

Consortium Salitre, 2015. Production Data in March of 2015. https://docs.google $\mathrm{com} /$ viewer? $\mathrm{a}=\mathrm{v} \&$ pid=sites\&srcid=Y29uc29yY2lvc2FsaXRyZS5jb218d3d3fGd 4OjZmZDBlOGQOMDFkNDJhYjE.

Costa, N.D., Yuri, J.E., Giongo, V., Angelotti, F., 2017. Sistema convencional de produção de melão no Submédio do Vale do São Francisco (Melon production in the conventional system adopted in the São Francisco Valley). In: Figueirêdo, et al. (Eds.), Produção de melão e mudanças climáticas. Embrapa, Fortaleza. https://www.embrapa.br/busca-de-publicacoes/-/publicacao/1074500/ producao-de-melao-e-mudancas-climaticas-sistemas-conservacionistas-decultivo-para-reducao-das-pegadas-de-carbono-e-hidrica.

Ellert, B.H., Bettany, J.R., 1995. Calculation of organic matter and nutrients stored in soil under contrasting management regimes. Can. J. Soil Sci. 75, 529-538.

Embrapa - Empresa Brasileira de Pesquisa Agropecuária, 2008. Crop Collection Green Corn (Coleção Plantar-milho-verde). Embrapa Informação Tecnológica, Brasília- DF, p. 61 (Coleção Plantar, 59).

Food and Agriculture Organization (FAO), 1997. Irrigation Potential in Africa: a Basin Approach. http://www.fao.org/docrep/W4347E/w4347e00.htm\#Contents.

Faria, C.M.B., Costa, N.D., Faria, A.F., 2007. Chemical attributes of an argisol and melon yield as affected by green fertilizers, liming and fertilization. Rev. Bras. Ciênc. Solo 31, 299-307.

Figueirêdo, M.C.B., Croeze, C., Potting, J., Barros, V.B., Aragão, F.A.S., Gondim, R.S., Santos, T.L., Boer, I.J.M., 2013. The carbon footprint of exported Brazilian yellow melon. J. Clean. Prod. 47, 404-414.

Figueirêdo, M.C.B., De Boer, I.J.M., Kroeze, C., Barros, V.S., De Sousa, J.A., De Aragão, F.A.S., Gondim, R.S., Potting, J., 2014a. Reducing the impact of irrigated 
crops on freshwater availability: the case of Brazilian yellow melons. Int. J. Life Cycle Assess. 19, 437-448.

Frischknecht, R., Althaus, H.J., Doka, G., Dones, R., Heck, T., Hellweg, S., 2007. Overview and Methodology. Final Report Ecoinvent v2.0 No. 1. Swiss Centre for Life Cycle Inventories.

Garcia-Franco, N., Albaladejo, J., Almagro, M., Martínez-Mena, M., 2015. Beneficial effects of reduced tillage and green manure on soil aggregation and stabilization of organic carbon in a Mediterranean agroecosystem. Soil Tillage Res. 153, $66-75$.

Giongo, V., Salviano, A.M., Santana, M.S., Costa, N.D., Yuri, J.E., 2016. Soil management systems for sustainable melon cropping in the submedian of the São Francisco Valley. Rev. Caatinga 29 (3), 537-547.

Goedkoop, M., Heijungs, R., Huijbregts, M., De Schryver, A., Struijs, J., Zelm, R.V., 2013a. ReCiPe 2008: a Life Cycle Impact Assessment Method Which Comprises Harmonised Category Indicators at the Midpoint and the Endpoint Level. Netherlands.

Goedkoop, M., Oele, M., Leijting, J., Ponsioen, T., Meijer, E., 2013b. Introduction to LCA with SimaPro. PRé-Consultants, Netherlands.

Intergovernmental Panel on Climate Change (IPCC), 2007. Climate Change (2007): Synthesis Report: Contributions of Working Group I, II and III to the Fourth Assessment Report. IPCC, Geneva. http://www.ipcc.ch/pdf/assessment-report/ ar4/syr/ar4_syr_sp.pdf.

International Organization for Standardization (ISO), 2006a. ISO 14040:2006Environmental Management, Life Cycle Assessment, Principles and Framework. ISO, Geneva.

International Organization for Standardization (ISO), 2006b. ISO 14044:2006Environmental Management - Life Cycle Assessment - Requirements and Guidelines. ISO, Geneva.

Instituto Brasileiro de Geografia e Estatística (IBGE), 2015. County Agriculture Production in 2013 (Produção Agrícola Municipal Em 2013). http://www.sidra. ibge.gov.br.

Ministério da Ciência e Tecnologia (MCT), 2010. Brazilian Inventory of Greenhouse Gases from Antropic Sources and Sinks Not Controlled by Montreal Protocol (Inventário Brasileiro de Emissões Antrópicas por Fontes e Remoções por Sumidouros de Gases de Efeito Estufa não Controlados pelo Protocolo de Montreal). MCT, Brasília.

Mendes, A.M.S., Faria, C.B.B., Silva, D.J., 2016. Fertilization (Adubação). In: Costa, N.D. (Ed.), Melon production system (Sistema de Produção de melão), Sistema de Produção do Melão [Melon production system]. ISSN: 1807-0027. https://www. spo.cnptia.embrapa.br.
Nemecek, T., Schnetzer, J., 2012. Methods of Assessment of Direct Field Emissions for LCIs of Agricultural Production Systems. Zurich.

Nemecek, T., Hayer, F., Bonnin, E., Carrouée, B., Schneider, A., Vivier, C., 2015. Designing eco-efficient crop rotations using life cycle assessment of crop combinations. Eur. J. Agron. 65, 40-51.

Paula Pessoa, P. F. A. de, Silva, M. G. O. da, Maia, C.W.C.P., 2017. Viabilidade econômica de sistemas convencionais e conservacionistas de cultivo de melão no Polo Jaguaribe-Açu. In: Figueirêdo, M. C. B. de, Gondim, R.S., Aragão, F. A. S. de (Eds.), Produçao de Meláo e Mudanças Climáticas: Sistemas conservacionistas de cultivo para redução das pegadas de carbono e hídrica Embrapa, Brasília, pp. 283-302.

Peche Filho, A., Ambrosano, E.J., Luz, P.H.C., 2014. Semeadura e manejo da biomassa de adubos verdes. In: Lima Filho, O.F., Ambrosano, E.J., Rossi, F., Carlos, J.A.D. (Eds.), Adubação verde e plantas de cobertura no Brasil, Fundamentos e Prática, vol. 1. EMBRAPA, Brasília, pp. 170-189.

Pereira Filho, A., Teixeira Filho, J.E., Giongo, V., Lima Simoes, W., Lal, R., 2016. Nutrients dynamics in soil solution at the outset of no-till implementation with the use of plant cocktails in Brazilian semi-arid. Afr. J. Agric. Res. 11, 234-246.

Rosenbaum, R.K., Bachmann, T.M., Gold, L.S., Huijbregts, M.A.J., Jolliet, O., Juraske, R. Köhler, A. Larsen, H.F. Macleod, M., Margni, M., McKone, T.E., Payet, J. Schuhmacher, M., Van de Meent, D., Hauschil, D.M.Z., 2008. USEtox - The UNEPSETAC toxicity model: recommended characterisation factors for human toxicity and freshwater ecotoxicity in Life Cycle Impact Assessment. Int. J. Life Cycle Assess. 13, (7), 532-546.

Singogo, W., Lamont Jr., W.J., Marr, C.W., 1996. Fall-planted cover crops support good yields of musck melons. HortScience 31 (7), 62-64.

Souza, F.H.D., Frigeri, T., Moreira, A., Godoy, R., 2007. Guandu Bean seeds production (Produção de sementes de Guandu). Embrapa Pecuária Sudeste. Documento 69. http://www.cppse.embrapa.br/sites/default/files/principal/publicacao/ Documentos69.pdf.

Teófilo, T.M.S., Freitas, F.C.L., Medeiros, J.F., Fernandes, D., Grangeiro, L.C. Tomaz, H.V.Q., Rodrigues, A.P.M.S., 2012. Water use efficiency and weed interference in melon crop under conventional and no-tillage systems. Planta Daninha 30 (3), 547-556.

Valentini, L., Oliveira, L.A.A., Ferreira, J.M., 2009. Corn seed production in microwaterbasins: Produção de sementes de milho variedade para uso próprio em propriedades de microbacias hidrográficas. ISSN: 1983-5671, vol. 15. Programa Rio Rural-Manual Técnico, Niterói- RJ. http://www.pesagro.rj.gov.br| downloads/riorural/15\%20Producao\%20de\%20Sementes\%20de\%20Milho.pdf. 